\title{
NA OKRAJÍCH MODERNÍHO POLSKÉHO BIBLICKÉHO PŘEKLADU: TEXT PÍSMA V NESTANDARDNÍCH JAZYKOVÝCH PODOBÁCH*
}

J O S E F B A R T O Ň

\begin{abstract}
Marginal Notes on Modern Polish Biblical Translation: Scripture Text in Non-Standard Language Forms

In the Polish environment, several translations (quasi-translations, adaptations) of biblical texts to dialects and a sociolect (slang) have been made in the last twenty years. Specifically, these are biblical texts in the Silesian and Goralian (Podhalanian) dialect, in which the whole New Testament was published as well as one text in the hip-hop sociolect (the Gospel according to John). The article presents the shape of these texts and comments on the circumstances of their ori-
\end{abstract} gin, existence, and status in Polish society.

Key words:

Modern Polish Bible translation; Silesian dialect; Goralian (Podhalanian) dialect; Polish hip-hop sociolect; Biblical text in a dialect and sociolect

DOI: $10.14712 / 23363398.2020 .49$

$\mathrm{O}_{\mathrm{d}}$ počátku nového tisíciletí v polském prostředí v rychlém sledu vzniklo a bylo publikováno několik jazykově nezvyklých biblických textů, převodů do lokálního dialektu (nářečí) nebo sociolektu (mluvy sociální skupiny). Použití těchto jazykových kódů pro biblický text představuje nový a překvapivě nikoli marginální fenomén, který naše (českojazyčné) prostředí prakticky vůbec nezná. ${ }^{1}$

* Studie je výsledkem autorova pobytu na Katedře dějin jazyka a dialektologie Fakulty polonistiky Jagellonské univerzity v Krakově (září 2018 - únor 2019) v rámci projektu OPVVV reg. č. CZ.02.2.69/0.0/0.0/16_027/0008495.

1 Za slabou a velice vzdálenou českou analogii můžeme považovat snad jedině několik málo jednotlivých slov či obratů z obecné češtiny a slezského 


\section{Tradice polského biblického překladu}

Ve většině období svého rozvoje se biblický překlad u našich severních sousedů a blízkých jazykových příbuzných nemohl srovnávat s biblickou překladovou tradicí českou. ${ }^{2}$ Kompletní česká bible byla dokončena již v polovině 14 . století. Do konce 15 . století byly k dispozici už čtyři překladové verze (tzv. redakce) staročeské bible, doložené v desítkách rukopisů, čeština má i dva prvotisky celé bible. Staropolská překladová tradice je naproti tomu o mnoho mladší a velmi slabě rukopisně doložená (Bible královny Žofie, torzo nejstarší, patrně již celé polské bible, je až z druhé poloviny 15. stol.). Celý text bible je doložen až v krakovském katolickém tisku z r. 1561 (tzv. Bible Leopolity). Hluboko do 16 . století je v polských překladech patrný silný český vliv. ${ }^{3}$ Teprve v období od poloviny 16 . do první třetiny 17 . století se polské překládání Písma intenzivně rozvíjí a vydává četné, stále samostatnější plody, v souvislosti s konfesním zápolením. V této době vzniká pět celých biblí v polštině (včetně výše už zmíněné Bible Leopolity), nemluvě o několika Nových zákonech, žaltářích a dalších dílčích překladatelských počinech. Dva nejvýznamnější plody této aktivity (jezuitská Bible Jakuba Wujka z r. 1599 a protestantská Bible gdaňská z r. 1632) se pak na dlouhou dobu staly texty natolik „klasickými“, že až do druhé poloviny 20. stol. byly polské biblické překladatelské pokusy

dialektu v nedávno publikované tzv. Parabibli, sbírce parafrázovaných biblických perikop (Alexandr Flek, Parabible: Tisková zpráva o našem prezidentovi Ježiši z Nošovic /Praha: Biblion, 2018/), případně pět krátkých evangelních perikop v brněnském hantecu, jež kolují po internetu jako zdroj specifické jazykové zábavy. K těmto zvláštním českým počinům viz Josef Bartoň, „Nietradycyjne formy czeskiego tekstu biblijnego“, Dialog z tradycja, t. VIII (Dziedzictwo antyczne $i$ biblijne $d z i s ́$ ), red. Magdalena Ryszka-Kurczab - Magdalena Puda-Blokesz (Kraków: Collegium Columbinum, 2020), 285-301.

2 Starší dějiny polské bible dopodrobna rozebrala již před půlstoletím v dosud nepřekonané rozsáhlé dvoudílné monografii Maria Kossowska, Biblia w języku polskim. I, II. (Poznań: Księgarnia Św. Wojciecha, 1968, 1969). Zatím dva objemné svazky (díly I a V) plánovaných nových šestidílných dějin polské bible (pojatých spíše bibliologicky) nedávno publikoval Rajmund Pietkiewicz, Biblia Polonorum. Historia Biblii w języku polskim. I (Od poczatku do 1638 r.), V (Biblia Tysiaclecia) ( Poznań: Pallotinum, 2016, 2015).

3 K rozsáhlým českým vlivům na polské středověké a renesanční bible viz např. Vladimír Kyas, Česká bible v dějinách národniho písemnictvi (Praha: Vyšehrad, 1997), 120-123 a 172-173; Robert Dittmann - Jarosław Malicki, "Mutual Relations between Polish and Czech Bibles in the Early Modern Period", Word of God, Words of Men. Translations, Inspirations, Transmissions of the Bible in the Polish-Lithuanian Commonwealth in the Renaissance, ed. Joanna Pietrzak-Thébault (Göttingen: Vandenhoeck \& Ruprecht, 2019), 205-228. 
nečetné: za tři a půl století mezi Wujkem (a protestantskou Biblí gdaňskou) a moderní římskokatolickou Biblí tisíciletí (Biblia Tysiaclecia) ${ }^{4}$ z r. 1965, která se vzápětí stala vůdčím katolickým překladem (užívaným také v liturgii), vzniklo jen jediné nové přetlumočení celé bible, a to v marginálním prostředí malé polské církve mariavitů (NZ 1921, SZ 1927; tento málo známý překlad byl proveden z Vulgáty). Období od Bible tisíciletí (zavádím značku: BT) však přineslo množství nových přetlumočení Písma: včetně $B T$ bylo dodnes kompletováno třináct nových biblí v polštině ${ }^{6}$ a několik dalších překladových projektů je v běhu. Polské jazykové prostředí tak v posledních pěti dekádách překladatelskou aktivitou poprvé kvantitativně předstihlo oblast českou (která přitom ovšem nebyla nijak pasivní: především za posledních padesát let vzniklo sedm nových celých českých biblí). ${ }^{7}$

\section{Biblický text v nestandardních jazykových podobách}

Přibližně v posledním dvacetiletí se v Polsku objevila také celá řada př́padů, kdy jsou biblické texty převáděny do nestandardnich

4 Označení Bible tisícileti ukazovalo na nadcházející tisícileté výročí křtu knížete Měška I. (966), tj. „pokřtění Polska“.

5 Text $B T$ uvádím ve znění 4 . vyd. z r. 1996.

6 Pokud je mi známo, neexistuje studie zabývající se souhrnně nejnovějšími polskými biblickými překlady. K počtu 13 jsem dospěl na základě vlastních rešerší (a konzultací s kol. dr hab. Marcinem Majewským z UPJP2 Kraków). Jde o tyto moderní překlady kompletu bible do polštiny (v závorce uvádím rok prvního vydání celku bible): 1 . Biblia Tysiaclecia (1965); 2. Biblia Poznańska (1975); 3. Biblia Warszawska (1975); 4. Biblia Warszawsko-Praska (1997); 5. Pismo Święte w Przektadzie Nowego Świata (1997); 6. Pismo Święte. Najnowszy przektad z języków oryginalnych z komentarzem (tzv. Biblia Paulistów; 2008); 7. Grecko-polski Nowy Testament (przekład interlinearny) (1993) / Hebrajsko-polski Stary Testament (przektad interlinearny) (2003-2010) / Grecko-polski Stary Testament - Księgi greckie (przekład interlinearny) (2008); 8, Nowa Biblia gdańska (2012); 9. Biblia pierwszego Kościoła (2016; SZ je přeložen ze Septuaginty); 10. Biblia Ewangeliczna. Przekład literacki (2016); 11. Uwspótcześniona Biblia gdańska (2017); 12. Biblia Ewangeliczna. Przektad dostowny (2018); 13. Biblia Ekumeniczna (2018).

7 Jde o tyto kompletní české bible: 1. Český ekumenický překlad (ČEP; 1979); 2. Křestanská řecká písma / Překlad hebrejských písem (1982/1987; od 1991 jednosvazkový Překlad nového svéta); 3. Slovo na cestu (NZ) / Průvodce životem (SZ) (1989/2003; od 2011 jednosvazková celá bible pod názvem Slovo na cestu); 4. Nová Bible kralická (poslední díl 2008; od 2009 jednosvazková Bible: prekeklad 21. stoleti); 5. Jeruzalémská bible (poslední díl pracovního vyd. 2008; od 2009 jednosvazková); 6. Český studijní preklad (2009); 7. Pavlikưv studijní preklad (2014). K českým překladům moderního typu náleží ještě dvě kompletní bible (katolické) z doby před ČEP: Bible česká (1917-1925; SZ Jan N. Hejčl / NZ Jan L. Sýkora) a bible - spojení SZ Jana Hegera (1953-1958) a NZ Rudolfa Cola (1961). 
jazykových forem, odlišných od spisovného polského jazyka. Konkrétně jde o převody do několika lokálnich dialektů polštiny a také do jednoho neúplného jazykového útvaru, který může být charakterizován jako sociolekt, tj. mluva ohraničené, specificky vymezené sociální skupiny. Většina těchto výtvorů jsou kvazipřeklady ze spisovné polštiny (tj. sekundární, zprostředkované „překlady“ z již existujících překladů do polského jazyka), pouze zcela výjimečně (zatím jenom u nepř́liš rozsáhlých biblických knih či vybraných pasáží) se jedná o skutečný překlad z textu v původním biblickém jazyce, př́ípadně z latinské Vulgáty. Cílem následujícího výkladu bude pokus představit právě tyto polské moderní jazykově nestandardní podoby biblického textu, respektive ty významnější z nich. Nebudeme se přitom snažit dopodrobna popsat daný dialekt (sociolekt) a posoudit všechny aspekty jeho využití v příslušném (kvazi)překladu, nýbrž poukážeme spíše př́íladmo jen na některé výrazné jazykové rysy (v kontrastu k biblickým textům ve standardní polštině). Ilustrující pomůckou nám budou konkrétní textové ukázky. Současně se pokusíme u jednotlivých počinů vystihnout důležité okolnosti (kulturní, sociální, církevní, politické) související se vznikem, vydáním a recepcí.

Pozornost budeme věnovat pouze takovým převodům biblického textu, v nichž je znatelný záměr překladatele či adaptátora („kvazipřekladatele“) v podstatných rysech zachovat jak obsah původniny, tak formální obrys - tedy nový útvar by měl v zásadě kopírovat reálnou strukturu biblického textu (zhruba ve smyslu rozeznatelnosti tradičních versetů). Volná převyprávění (parafráze, biblické příběhy) necháme stranou, respektive pojednáme jen o jednom z takovýchto počinů. Zaměříme se také jen na „větší výtvory vydané knižně - a většinu z nich si zevrubněji představíme. Malé fragmenty a texty publikované jinak (otištěné časopisecky, v podobě subkapitolky nebo malé textové pasáže v knížce/sborníku či jenom vyvěšené na internetu) do našeho výkladu nezahrneme, resp. v případě potřeby budou některé z nich pouze okrajově zmíněny.

Stranou zorného pole této naší studie zůstanou biblické texty v kašubštině, řeči autochtonních slovanských obyvatel severních regionů Polska (na západ od Gdaňska), považovaných za potomky středověkých Pomořanů. Kašubština totiž sice byla v některých obdobích považována za pouhou skupinu dialektů polského jazyka, vykazuje však některé výrazné, specifické znaky, má starou svébytnou literární tradici a již nějakou dobu (od r. 2005) má v Polské republice také oficiální právní 
status regionálního jazyka. ${ }^{8}$ Kašubské biblické texty se od devadesátých let 20. století legálně používají při katolické mši (od r. 2007 je k dispozici i oficiální mešní lekcionář). Z devadesátých let mají Kašubové překlad čtveroevangelia z Neovulgáty a kvazipřeklad celého Nového zákona a žalmů z polštiny. Po r. 2000 postupně vycházejí nové překlady biblických knih (z původních jazyků) z pera Adama R. Sikory, profesora biblistiky na poznaňské Univerzitě Adama Mickiewicze (za těsné spolupráce předních lingvistů - znalců kašubštiny). ${ }^{9}$ Kašubština je dnes v Polsku víceméně všeobecně chápána jako etablovaný samostatný jazyk, ${ }^{10}$ významnou skutečností je, že její užití v biblických překladech je už řadu let oficiálně akceptováno církevními autoritami.

Nakolik se mi podařilo zjistit, ${ }^{11}$ z polských lokálních dialektů se v moderních překladech (či spíše kvazipřekladech, adaptacích) textů Písma, vzniklých a publikovaných v posledních dvou dekádách, uplatnila slezština (hornoslezština) a (podhalanská) góralština (která náleží k malopolským dialektům). V následujících dvou subkapitolách budou tedy představeny hlavní počiny, které byly realizovány v rámci těchto dialektů ( $\mathrm{v}$ případě slezštiny přitom lze hovořit spíše o celé skupině navzájem poměrně dost odlišných dialektů).

\subsection{Biblické texty slezské}

Pokud jde o biblické texty v slezských nářečích historického Horního Slezska, během posledních dvaceti let se objevilo několik větších knižních počinů, včetně kompletního Nového zákona, plus další méně významné pokusy (některé publikované jen na internetu). Je přriznačné,

8 Regionální jazyk je podle Evropské charty regionálních a menšinových jazyků (1992) vymezen jako jazyk tradičně užívaný (po nezanedbatelnou dobu) na území daného státu menší skupinou občanů, který se liší od úředního jazyka a není ani dialektem oficiálního jazyka daného státu, ani jazykem migrantů. Polsko uznává jediný regionálni jazyk, a to právě kašubštinu.

9 Nejstarší (fragmentární) biblické texty v „kašubizované polštině“ pocházejí ze 16. století. Po r. 2000 poznaňský biblista Adam R. Sikora publikoval již několik celých biblických knih přeložených z řečtiny a hebrejštiny (čtveroevangelium a Pentateuch) a další připravuje k vydání v blízké době. Srov. Josef Bartoň, „Kašubský biblický text v dávné minulosti a dnes“, Salve 20, č. 4 (2010): 161-165; Josef Bartoň, „Další svazek kašubské bible - kniha Genesis“, Opera Slavica 25, č. 4 (2015): 40-44.

10 Např. v nedávno uvedeném polském historickém filmu Filipa M. Bajona Kamerdyner (2018), kde je poprvé masivně využita kašubština (ve velmi vysokém procentu dialogů), jsou kašubské pasáže (stejně jako německé) doprovázeny polskými titulky (a to nikoli bez důvodu: kašubština je pro běžného rodilého uživatele polštiny srozumitelná dosti obtížně).

11 Vlastními rešeršemi a konzultacemi s krakovskými kolegy-filology (z nichž bych zvláště rád poděkoval dialektologovi dr. Arturu Czesakovi). 
že texty jsou jazykově i ortograficky dost různorodé, značná rozkolísanost (zejména v hláskosloví) je ve vysoké míře dána rozdílnostmi mezi jednotlivými slezskými nářečími. Tyto diference podle mínění řady lingvistů významně ztěžují či úplně znemožňují vytvoření možné fungující jednotné spisovné normy pro celou (horno)slezštinu. ${ }^{12}$

\subsubsection{Biblia Ślazoka}

V r. 2000 publikoval Marek Szołtysek (*1963; absolvent Katolické univerzity v Lublině, středoškolský učitel dějepisu a společenských věd, publicista a úspěšný slezský regionální spisovatel) z jihoslezského města Rybnik ve vlastním vydavatelství Ślaskie $A B C$ svou knížku Biblia Ślazoka („Bible Slezana“; zavádím značku: $B S$ ). ${ }^{13}$ Tato tenká, hojně ilustrovaná knížka velkého formátu (A4; necelých sto stran) se během času ukázala jako naprostý hit slezské regionální knižní produkce. Za pět let (do r. 2005) bylo prodáno sto tisíc výtisků, za patnáct let (do r. 2015) dokonce půl miliónu kusů a titul je i dnes (2019) nadále $\mathbf{v}$ prodeji. Jádrem svazku je soubor dosti volně převyprávěných biblických příběhů (jde $\mathrm{v}$ podstatě o žánr označovaný v polském prostředí jako historie či opowieści biblijne) spolu s více či méně paralelními aktualizujícími vyprávěními ze starší i moderní slezské reality, laděnými vážně i humorně. Např. jsou tu vedle sebe položeny dvojice textů Manna z nieba - Wegiel i przemyst jak manna z nieba („Nebeská mana - Uhlí a průmysl jako nebeská mana“) nebo Wzkrzeszynie Łazorza-Wzkrzeszynie Ślazoka („Vzkřríšení Lazara - Vzkř́íšení Slezana“). Některé oddíly knížky jsou veršované-rýmované, např. „poslezštěné“ verze lidových koled či rýmované vyprávění Przypowiyść o miłosiernym Gorolu („Podobenství o milosrdném Goralovi“, tj. Neslezanovi).

12 Otázku možného utváření slezského spisovného jazyka rozebírá a spíše optimistický výhled formuluje např. vratislavský slavista Henryk Jaroszewicz, „Współczesne kształtowanie się śląskiego języka literackiego (warstwa ortograficzno-gramatyczna)“; referát přednesený na konferenci Stowiańszczyzna dawniej i dziś-język, literatura, kultura, Uniwersytet Wrocławski, 4. - 5. dubna 2019; text byl dne 11. 4. 2019 dostupný na adrese https://www.facebook.com/pg/GodomyPoSlonsku/posts/ - status ze dne 28. března 2019. Opačný, výrazně skeptický pohled reprezentuje např. významný polonista starší generace Jan Miodek (*1946), sám také Slezan, působící desítky let na téže Vratislavské univerzitě, viz např. Teresa Semik - Jan Miodek, „Dyskusja o języku śląskim w piśmie jest żenująca“, Dziennik Zachodni, 26. 03. 2011; dne 5. 5. 2019 dostupné na adrese https://bit.ly/32pOYvZ. Současné pokusy o kodifikaci podrobně představuje také opolský polonista Bogusław Wyderka, „O standaryzacji języka śląskiego“, Kwartalnik opolski 64 (2018), č. 1, 4-18.

15 Marek Szołtysek, Biblia Ślazoka. Historia, kultura, gwara (Rybnik: Śląskie ABC, 2000). 
Všechny biblické příběhy jsou ve slezštině (v nářečí autorova města Rybnik, které patří do centrálního dialektu gliwického), naopak většina ostatních textů (včetně „paralelních“ vyprávění) je ve spisovné polštině.

Ukázka 1: L 1,26-32 ${ }^{14}$

BŚ Jednego dnia do miasta Nazaryt przyfurgnat $z$ nieba aniot Gabriel. Wloz do chatpy, kaj miyszkała tako jedno piykno a pobożno frelka Maryjka i tak do niej pedziot: Szczynść Boże Maryjko! Tyś je nojszykowniyjszo miyndzy innymi babami, bestoż Ponboczek kazoł ci pedzieć, że poczniesz

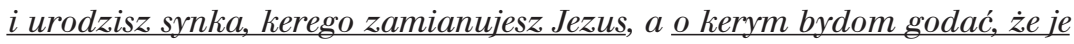
Ponboczkowym Synkiym. [...]

BT ${ }^{26} W$ szóstym miesiacu postał Bóg anioła Gabriela do miasta $w$ Galilei, zwanego Nazaret, ${ }^{27}$ do Dziewicy poślubionej mężowi, imieniem Józef, $z$ rodu Dawida; a Dziewicy byto na imie Maryja. ${ }^{28}$ Aniot wszedt do Niej i rzekt: "Badź pozdrowiona, petna taski, Pan z Toba». ${ }^{29}$ Ona zmieszała się na te stowa i rozważała, co miatoby znaczyć to pozdrowienie. ${ }^{30}$ Lecz anioł rzekt do Niej: «Nie bój się, Maryjo, znalazłaś bowiem taskę u Boga. ${ }^{31}$ Oto poczniesz i porodzisz Syna, któremu nadasz imie Jezus. ${ }^{32}$ Będzie On wielki i będzie nazwany Synem Najwyższego, [...]»

Bogner ${ }^{26} V$ šestém mésici byl andèl Gabriel poslán od Boha do galilejského mésta, které se jmenuje Nazaret, ${ }^{27} k$ panně zasnoubené s mužem jménem Josef $z$ Davidova rodu a ta panna se jmenovala Maria. ${ }^{28}$ Andèl $k$ ní vešel a rekl: "Bud' zdráva, milostiplná! Pán s tebou!«. ${ }^{29}$ Když to slyšela, ulekla se a uvažovala, co má ten pozdrav znamenat. ${ }^{30}$ Andèl jí rekl: "Neboj se, Maria, nebot' jsi nalezla milost u Boha. ${ }^{31}$ Počneš a porodiš syna a dáš mu jméno Ježís. ${ }^{32}$ Bude veliký a bude nazván Synem Nejvyššího. [...]"

Z ukázky je na první pohled jasné, že jde v zásadě o rozvolněnou parafrázi, kterou jako celek lze stěží označit za opravdový převod biblického textu (ze spisovné polštiny do dialektu). Jen u některých víceslovných sekvencí a jednotlivých výrazů (viz podtržení) je možno konstatovat, že Szołtyskovo znění víceméně odpovídá předlohovému

14 Text uvádím pro porovnání ve standardním polském znění BT a také v českém katolickém liturgickém překladu Václava Bognera (NZ 1989). U této perikopy volím raději překlad Bognerův, jehož znění více než Český ekumenický překlad (CEP) koresponduje s polskou $B T$. V ostatních ukázkách tohoto článku (viz níže perikopy Mk 1,1.9-11 a Ž 1,1-3) již uvádím český text ČEP. 
biblickému textu. Biblia Ślazoka by tedy vlastně striktně vzato nepatřila do ohniska zájmu tohoto našeho článku, nicméně nebylo možné ji ve výkladu pominout: byla totiž prvním významným slezským „biblickým počinem“ (knížka se rozšířila ve zcela masivním měřítku, srov. výše) a právě ona se brzy po vydání stala jedním z hlavních objektů diskusí o (ne)vhodnosti přetvářet biblický text do nestandardních jazykových podob polštiny. ${ }^{15}$ Patrně tomu bylo pro slovo Biblia v titulu, ač je autor nejspíš použil se záměrem dvojznačnosti: jednak s odkazem na Písmo svaté (protože podstatnou částí knížky jsou biblické příběhy), jednak v nadsazeném přeneseném smyslu („nezbytná příručka pro každého správného Slezáka“). I v rychlém porovnání se zněním standardní polské $B T$ vidíme, že text nejenže je samozřejmě pravopisně a gramaticky (hláskoslovně a morfologicky) specifický, ale je také celkem prosycen výraznými nářečními prvky lexikálními (przyfurgnać „přiletět“, v standardní polštině ${ }^{16}$ przyfrunać; frelka „dívka“, pol. dziewczyna; Ponboczek „Pán Bůh, Pánbíček“, pol. Bóg), které na recipienta přivyklého polskému standardu (a dokonce nejspíš u tohoto typu textu podvědomě očekávajícího vyšší, biblický styl) působí patrně automaticky výrazně příznakově, expresivně, komicky. Mimo naši ukázku narazíme mj. také na formy s protetickým neslabičným u(jež se zapisuje jako t-; např. tojciec „otec“, pol. ojciec; tod „od“, pol. $o d$ ), ovšem proteze není uplatňována důsledně (např. odpuszczynie „odpuštění“, pol. odpuszczenie; v naší ukázce o kerym „o kterém“, pol. o którym).

\subsubsection{Ewangelie ślaskie}

Zmíněný M. Szołtysek vydal za třináct let po své Biblii Ślazoka její jakoby „neformální pokračování“ , ${ }^{17}$ knížku Ewangelie ślaskie (2013; zavádím značku: $E S$ ). ${ }^{18}$ Tento svazek už ale obsahuje skutečné souvislé biblické texty převedené do slezštiny ( na śląska godkę). Konkrétně tu nalezneme celou starozákonní knihu Jonáš, pak tzv. evangelia dětství (kapitoly 1. a 2. evangelií podle Matouše a Lukáše) a zejména

\footnotetext{
Srov. níže subkap. 3.2.

Dále užíváme pro standardní (spisovnou) polštinu zkratku pol.

17 Sám Szołtysek v novinovém rozhovoru přímo říká, že je to tak naprawdę druga część „Biblii Ślązoka“ (Maria Zawała, „Ewangelie śląskie Marka Szołtyska. Nowy apokryf na znak... protestu“, Dziennik Zachodni, 11. 10.2013; 5. 4. 2019 dostupné na adrese https://bit.ly/2WsxWcK).

18 Marek Szołtysek, Ewangelie ślaskie (Rybnik: Śląskie ABC, 2013).
} 
celé evangelium Markovo. Tento počin je významný proto, že již nejde o pouhý kvazipřeklad ze standardního polského biblického překladu. Evangelní texty totiž Szołtysek překládal z originálního jazyka, tj. řečtiny (k ruce měl přitom také polské překlady a českou Bibli kralickou), u Jonáše pak překladateli jakožto předlohy posloužily (z důvodu neznalosti hebrejštiny) polské překlady a latinská Vulgáta. ${ }^{19} \mathrm{~V}$ knížce je také zařazeno několik nebiblických doprovodných textů (jako např. článek o slezských betlémech) a Szołtyskův autorský „apokryf“ Ewangelia ślaska wg św. Anny („Slezské evangelium podle sv. Anny“), kde autor ústy Ježíšovy babičky sv. Anny mj. kritizuje vypjatý antipolský slezský nacionalismus (hora sv. Anny, kde měl být text „nalezen“, je významným poutním místem Slezanů).

\section{Ukázka 2: Mk 1,1.9-1120}

EŚ ${ }^{1}$ Napoczyncie Ewangelie o Jezusie Krystusie, Ponboczkowym ${ }^{21}$ Synku. [... ${ }^{9}$ I praje wtedy prziszot tam Jezus ze Nazarytu we Galilyji i przijon od Jona krzest we Jordanie. ${ }^{10}$ A tela co wytaziot ze wody, to ujrzot odewrzynie sie nieba i Ducha, kery choby gotymbica na Niego zestympowot. ${ }^{11}$ A ze nieba odezwało sie godanie: „Tyś je moj Synek nojmilyjszy, kerymu tak fest przaja". [...]

BT ${ }^{1}$ Poczatek Ewangelii o Jezusie Chrystusie, Synu Bożym. $[\ldots]^{9} \mathrm{~W}$ owym czasie przyszedt Jezus $z$ Nazaretu $w$ Galilei i przyjat od Jana chrzest $w$ Jordanie. ${ }^{10} \mathrm{~W}$ chwili gdy wychodzit $z$ wody, ujrzat rozwierajace sie niebo i Ducha jak gotębice zstepujacego na siebie. ${ }^{11}$ A z nieba odezwat się głos: «Tyś jest mój Syn umiłowany, $w$ Tobie mam upodobanie». [...] ČEP ${ }^{1}$ Poćátek evangelia Ježíše Krista, Syna Božiho. [...] ${ }^{9} V$ těch dnech príšel Ježíšs z Nazareta $v$ Galileji a byl v Jordánu od Jana pokŕtén. ${ }^{10}$ Vtom, jak vystupoval z vody, uvidèl nebesa rozevrená a Ducha, který jako holubice sestupuje na nèj. ${ }^{11}$ A z nebe se ozval hlas: Ty jsi můj milovaný Syn, tebe jsem si vyvolil. [...]

19 Informace z osobní korespondence s Markem Szołtyskem z 31. 1. 2019. V publikaci samé se píše o řecké předloze u evangelií, u Jonáše není původnina uvedena.

20 Text uvádím pro porovnání také ve standardním polském znění BT a v Českém ekumenickém préekladu $(\check{C} E P)$.

21 Ve výrazu Ponboczkowym (a jinde v textu ukázky) zvláštním způsobem vysázené o označuje specifickou samohlásku, vyslovovanou jako zvuk mezi [o] a [u] (v naší ukázce tuto literu sázíme stojatě a tučně; v Szołtyskově knížce, jež má naopak základní text stojatý, je sázena polotučnou kurzívou). 
V textu je použit týž dialekt jako v Biblii Ślazoka (středoslezský, centrálněgliwický). Podobně jako v $B S ́$ zachází autor s lexikem, v textu např. ponechává deminutivní formy Ponboczek, Synek (srov. v. 1 a 11), jež u běžného uživatele standardní polštiny nepochybně působí dojmem expresivity - mazlivosti či domáckosti (a vposledku zde je opět patrné riziko vyvolání nezamýšleného komického účinku na čtenáře či posluchače). Zajímavé je, že se Szołtysek rozhodl v EŚ rezig-

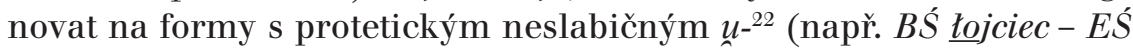
ojciec „otec“, pol. ojciec; BŚ tobwinyta go - EŚ obwinyta go „ovinula ho“, pol. owinęta go). Formy s protezí autor patrně tentokrát vyhodnotil (na pozadí standardní polštiny) jako př́lišs „lidové“ pro opravdový biblický text.

\subsubsection{Nowy Testamynt po ślonsku}

Slezština se nakonec před nedávnem (v září 2017) dočkala také vydání celého Nového zákona. Tento text vytvořil a vydání obstaral dlouholetý starosta malého východoslezského města Radzionków Gabriel Tobor ( ${ }^{* 1961 ; ~ j e h o ~ p r o f e s n i ́ ~ z a m e ̌ r ̌ e n i ́ ~ i ~ v z d e ̌ l a ́ n i ́ ~ j e ~ t e c h n i c k e ́ ~ a ~ e k o n o m i c k e ́, ~}$ doktorátu dosáhl na Ekonomické univerzitě v Katovicích; desítky let se zajímá o překlady Písma: ve své sbírce má zhruba 200 překladů do asi 90 různých jazyků). Jeho Nowy Testamynt po ślonsku (zavádím značku: $N T S)^{25}$ je kvazipřeklad do autorova rodného nářečí oblasti města Radzionkowa, tj. dialektu hornoslezsko-malopolského pomezí; východiskem pro adaptaci byla „klasická“ bible Jakuba Wujka (1599; zavádím značku: $B W$ ). Práce je zajímavá právě tím, že Tobor sice použil místní živý dialekt, ale v kombinaci s volbou „velebné“ polské renesanční předlohy (Wujek). V klasické předloze autor zjevně hledá zdroj pro „povznesení“ dialektu, jeho obohacení prvky knižního, vysokého stylu. V podstatě tedy před sebou máme pozoruhodný pokus konstituovat v dialektu zvláštní biblický styl.

Ukázka 3: Mk 1,1.9-11 ${ }^{24}$

NTŚ ${ }^{1}$ Pocontek Ewangelji Jezusa Chrystusa, Syna Bożego. [...] ${ }^{9}$ W tym casie prziciongnot Jezus ze Nazarytu we Galileji i tostot tokrzcony przes Jana we Jordanie. ${ }^{10}$ We kwili kej wytaziot $z$ wody, tobocot totwarte niebo i Ducha

22 Následující př́iklady vybírám z jiných míst než z prezentované ukázky.

23 Gabriel Tobor, Nowy Testamynt po ślonsku (Radzionków: Szymon Tobor, 2017).

24 Text uvádím pro porovnání také v polském „klasickém“ znění $B W$, jež bylo G. Toborovi hlavním vzorem. České znění perikopy v ČEP viz výše v ukázce 2. 
jako gołomb, ftory sfurgnot na Niego. ${ }^{11}$ I todezwot sie z nieba gtos: Tyś jes moj Synek, ftorymu przaja, ftoryś jes mi roztomity, [...]

BW ${ }^{1}$ Poczatek Ewánjelijéj Jesusá Christusá syná Bożégo. [... ${ }^{9}$ I zstáło sie: w oné dni przyszedt Jesus od Názáret Gálilejskiégo: i ochrzczon jest od Janá w Jordanie. ${ }^{10}$ A nátychmiast wystapiwszy z wody, ujżrzat otworzoné niebiosá, i Duchá jáko gotębicę zstępujacégo i trwájacégo ná nim. ${ }^{11}$ I zstat sie gtos z niebá: Tyś jest syn mój mity, $w$ tobie mi sie upodobáto. [...]

V porovnání s $B S ́$ (srov. ukázka 1) a EŚ (viz ukázka 2) je i pro českojazyčného laika-nelingvistu na první pohled zřejmé, že u Tobora se jedná o odlišné slezské nářečí: v NTŚ je nápadné zejména tzv. mazurení (tj. $c, s, z, d z$ namísto etymologického $c ̌ c, s, z$, $d \grave{z}$; srov. např. v. 1 NTŚ pocontek proti EŚ napoczyncie). ${ }^{25}$ Tobor také důsledně uplatňuje protetické neslabičné u- (psané jako $t$-; srov. v. 10 NTŚ totwarte niebo - naproti tomu v EŚ je odewrzynie sie nieba bez protetické hlásky). Významnou charakteristikou NTŚ, zjevně v souladu s tíhnutím k vysokému stylu (vzorem je Wujkův překlad), je samozřejmě „tradičnější” výběr většiny jazykových prostředků (srov. v. 1 NTŚ Syna Bożego - EŚ Ponboczkowym Synku; Tobor zde ve spojení „Syn Boži“ neužil deminutivních forem, přestože o něco dále ve v. 11 zvolil podobu Synek).

Povšimnutí hodným momentem pak je, že mazuření (znak vlastní radzionkowskému dialektu, společný se sousedními dialekty malopolskými) je v Toborově textu dost viditelně uplatňováno nedůsledně. ${ }^{26}$ Př́́klady s mazuřením: $w$ tym casie „, tom čase“, pol. $w$ tym czasie; juz „už“, pol. już; bijes „biješ“, pol. bijesz; pomocony „namočený“, pol. pomoczony. Proti tomu ale jsou dost časté formy bez mazuření: Syna Bożego „Syna Božího“, pol. Syna Bożego; mjecz „meč“, pol. miecz;

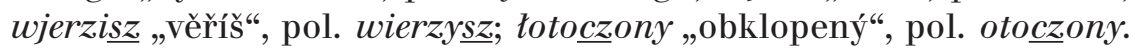
Vyskytují se také případy, kdy v jednom výrazu nebo sousloví je forma mazuřící i nemazuřící zároveň: możes „můžeš“, pol. możesz; życie wiecne „život věčný“, pol. $\underline{z} y c i e$ wieczne. Dokonce lze narazit na týž tvar téhož výrazu, jednou s mazuřením, jednou bez něho: J 11,20 Marta ustyszała („uslyšela“, pol. ustyszata) - avšak J 11,29 (v blízkém sousedství!) tamta to ustys $\underline{a} a \nmid$. Je těžké jednoznačně určit, čím konkrétně jsou tyto frapantní rozkolísanosti motivovány. Snad tím, že sám autor

\footnotetext{
25 Mazuření je jev typický pro dialekty Mazur, Mazovska, Malopolska a také právě pro severní a východní části Horního Slezska.

26 Následujících několik př́íkladů vybírám i z jiných míst než jen z prezentované ukázky.
} 
živelně spoléhal na „cit” rodilého mluvčího nářečí, které už samo o sobě není „čisté“? Nebo spíš autorovi do psaného textu spontánně pronikaly formy ze standardní polštiny? A dost možná, že aspoň za některými volbami je i vědomý záměr, podložený např. pocitem, že určitá „kulturní” slova (jako Boży „Boži“, życie „život“, mjecz „meč“) je vhodné nevzdalovat od standardní polské podoby?

\subsubsection{Jiné slezské pokusy}

Vedle uvedených nejviditelnějších, „větších“ pokusů převést biblický text do slezského dialektu je k dispozici také celá řada menších či méně viditelných počinů, z nichž tři zde alespoň stručně zmíníme.

Na internetu bylo publikováno slezské znění celé starozákonní poetické knihy Píseň pisní, které nese vročení 2000 - je to tedy text dost raný, časově souběžný s knížkou Biblia Ślazoka. Autorem je Edward Dornia, žijící (již dlouhou dobu) v kanadském Vancouveru a angažující se v kanadské zahraniční Polonii. Dorniův slezský text je zachycen zjednodušeným, tzv. „internetovým“ pravopisem (bez diakritiky). ${ }^{27}$

Vydání ve formě knížky (2013) se dočkal převod (z němčiny a polštiny) části starozákonní knihy Genesis (kap. 1-19) z ruky Ireneusze Czaji, píšícího pod pseudonymem Szwager z Laband (Łabędy, něm. Laband, je součást středohornoslezského města Gliwice), ${ }^{28}$ pobývajícího dlouhodobě v Německu, ale aktivního v zapojení do slezského „národního života“. Text redigoval Andrzej Roczniok, aktivista významně angažovaný v slezském kulturním životě i v autonomistickém hnutí. Zajímavostí knížky je skutečnost, že text je vysázen dvakrát (zrcadlově) - ve dvou pravopisných systémech: jednak „internetovým“ pravopisem, jednak „standardni““ ortografí, jež je pokusem o pravopisnou kodifikaci celé hornoslezštiny (tato ortografie víceméně realizuje tzv. téšinské pravopisné zásady z r. $2009 ;{ }^{29}$ ty jsou také prezentovány jako samostatný oddíl v závěru knížky spolu s přidanou kapitolkou o psaní velkých písmen, jejímž autorem je zmíněný A. Roczniok). Část

\footnotetext{
Text byl 20. 7. 2019 dostupný na adrese https://bit.ly/32pQYUY.

28 Biblijo: poczōntek. Przetuplikowoł na ślōnsko godka Ireneusz Czaja (Szwager z Laband) (Zabrze: Narodowa Oficyna Śląska, 2013).

$29 \quad$ Jde o dokument Wstępne zasady pisowni ślaskiej przyjęte na spotkaniu $w$ Cieszynie $w$ dn. 10 sierpnia 2009 r. przez zespót do standaryzacji pod kierownictwem prof. J. Tambor; 20. 7. 2019 dostupné na adrese https://bit.ly/3fO62Qd. Tyto zásady se označují různě, např. Kanōna szrajbowanio Ślōnskij Godki (internetová strana organizace Związek Ludności Narodowości Śląskiej) či Ślabikŏrzowy szrajbōnek (slezská Wikipedia).
} 
vytištěná „standardně“ vykazuje i některé menší odlišnosti v samém textu (nejen v ortografii), jež jsou pravděpodobně prací A. Rocznioka.

Pozoruhodnou iniciativu rozvíjí na svém internetovém blogu Andrzej Cichoń (z města Ruda Śląska ve středním Horním Slezsku): už od r. 2016 publikuje postupně své slezské verze nedèlnich mešních perikop (hlavně evangelních, někdy i z jiných částí Písma) ${ }^{30}$ přičemž východiskem jsou mu texty Biblii Tysiaclecia. ${ }^{31}$ Nečiní to zcela pravidelně každý týden, ale $\mathrm{v}$ každém případě dnes již je počet těchto perikop v řádu stovek. Zajímavostí je, že Cichoń nejprve (v říjnu 2016) začal zveřejňovat ve slezštině „aktualizující parafráze“ evangelních čtení, tj. děj přenášel ze starověkého Blízkého východu do současného Slezska. ${ }^{32}$ Zanedlouho (už během listopadu 2016) však přešel na slezské adaptace perikop bez aktualizací $\mathrm{v}$ místě a čase. ${ }^{33}$

\subsection{Biblické texty góralské (podhalanské)}

Přesuneme nyní pozornost dál na východ, do svérázného a dosud národopisně živého regionu Podhale (č. Podhali). ${ }^{34}$ Podhalanská (podhalská) náréč́ zdejších Góralů náleží do skupiny dialektů malopolských a jako jeden z nejnápadnějších znaků odlišujících je od spisovné polštiny v nich (stejně jako v jiných nářečích malopolské skupiny) shledáváme mazuření (o němž už byla řeč výše v subkap. 2.1.3).

\subsubsection{Nowy Testament po góralsku}

Už v r. 2002 vyšlo tiskem čtveroevangelium v góralském nářečí z pera Marie Matejowé Torbiarz ( ${ }^{* 1945 ; ~ v y s t u d o v a n a ́ ~ h i s t o r i c ̌ k a ; ~ d e s i ́ t-~}$ ky let byla pracovnicí městského úřadu v městě Zakopane, angažovala se významně v góralské kultuře a její popularizaci, publikovala

30 Adresa blogu s perikopami (ke dni 20. 7. 2019): https://bit.ly/3fB7sxd.

31 Informace z osobní korespondence s A. Cichońem ze dne 1. 8. 2019.

32 Jeho př́stup byl tedy náhodnou shodou okolností podobný jako v české Parabibli A. Fleka (srov. výše v pozn. 1). Nejstarší zveřejněná perikopa (L 17,11-19) ve stylu „aktualizující parafráze“ je z 9. 10. 2016: místo Jeruzaléma jde Ježíš do Katovic, místo deseti malomocných jsou zde smrdící žebráci, místo velekněze arcibiskup, místo Samařana tu figuruje Gorol, jakožto protiklad Slezana (20. 7.2019 dostupné na adrese https://bit.ly/2Owvbmi).

33 A. Cichoń upustil od „aktualizováni““ - cituji jeho slova - na skutek reakcji czytelników, których taka wersja rozśmieszała, a ja nie miałem zamiaru robić z Biblii humoreski (osobní korespondence s A. Cichońem ze dne 1. 8. 2019).

34 Region na sever od Vysokých Tater, jehož střední osa probíhá městy Zakopane a Nowy Targ a jehož severní hranici tvoří pohoří Gorce. 
i básně). V r. 2005 autorka vydala svazek obsahující zbývající novozákonní knihy (apoštolář), celek Nového zákona vyšel v témž roce v jediném svazku (zavádím značku NTG - Nowy Testament po góralsku). ${ }^{35}$ Podkladem pro její text byl polský překlad Biblii Tysiaclecia.

\section{Ukázka 4: Mk 1,1.9-1136}

NTG ${ }^{1}$ Pocontek Ewangelije o Jezusie Krystusie, Synu Bozym. $[. ..]{ }^{9}$ Ftyncos przyset Jezus s Nazaretu $w$ Galileji i przyjon od Jona krzest $w$ Jordanie. ${ }^{10}$ Ftej, kie wychodziyt s wody, uwidziot ozwiyrajonce sie niebo i Ducha jako gotymbice zstympujoncego na sie. ${ }^{11}$ A s nieba obezwoł sie głos: «Tyś mój Syn, co cie rod widzem, ${ }^{37}$ Ty sie mi widzis.» [...]

V ukázce si i český čtenář ihned všimne - v protikladu k spisovnému polskému textu $B T$ - zejména typického mazuření (které je v NTG uplatněno velmi razantně ${ }^{38}$ - v porovnání se slezským NTŚ, po této stránce výrazně rozkolísaným, srov. výše), např. pocontek, Synu Bozym (v. 1), przys set (v. 9), widzis (v. 11). Jako deficit lze vytknout např. rezignaci na uplatnění velmi typického znaku daného dialektu, tzv. podhalanského archaismu (tj. neprovedení polského „ztvrdnutí“v původních měkkých slabikách $c ̌ i, s ̌ i$, ži /posléze „zmazuřených“/ a rozšíření měkkého [i] také do původních pozic $c y, s y, z y)$, např. ve v. 1 o Synu Bozym „o Synu Božím“, pol. o Synu Bożym („důsledně podhalansky“ by bylo:

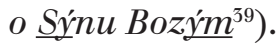

\subsubsection{Tatrzański Psatterz Dawidowy}

V r. 2003 publikoval knížku Tatrzański Psatterz Dawidowy. Część pierwsza („Tatranský žaltář Davidův. První část“; zavádím značku $T P D)^{40}$ Franciszek Bachleda-Księdzularz (1947-2019; vzděláním filolog-polonista; od devadesátých let angažovaný v politice lokální, regionální i celostátní, 1993-2005 senátor za województwo nowosądeckie;

35 Nowy Testament. W przekładzie Marii Matejowej Torbiarz na gwarę Górali skalnopodhalańskich z Zakopanego. Praca studijna na podstawie Biblii Tysiąclecia (Poznań: Pallotinum / Zakopane-Krzeptówki: Sanktuarium Matki Bożej Fatimskiej, 2005). Nowy Testament po góralsku je neformální označení.

36 Polské znění BT a české znění ČEP viz výše v ukázce 2.

37 Odlišná sazba znamená odkaz na text SZ (zde: Iz 42,1).

38 I zde však lze občas narazit na nedůslednosti, např. v Mt 10,2-3 syn Zebedeus $a$ - syn Alfeusza, Mateus-Tadeusz.

39 Existují různé způsoby zápisu onoho [i]; ý je jedna z běžně užívaných možností.

40 Franciszek Bachleda-Księdzularz, Tatrzański Psatterz Dawidowy. Część pierwsza (Kraków: Wydawnictwo AA, 2003). 
básník). Knihu nebylo možno zakoupit, autor ji sám rozdával přátelům a zájemcům. Z vydavatelského pohledu jde tedy spíš o exkluzivní počin, na druhou stranu je jisté, že se i dnes po vyčerpání nákladu mezi zájemci šírí formou skenů (ve formátu pdf). Svazek obsahuje vybrané žalmy (asi čtvrtinu žaltáře) zveršované do podhalanského góralského dialektu. Autor při tvorbě své adaptace vycházel z několika polských biblických překladů (Biblia Wujka, Biblia Tysiaclecia, žalmy básníka Czesława Miłosze) a zvlášt' se inspiroval v proslulém renesančním přebásnění žalmů Jana Kochanowského (1579). ${ }^{41}$

Ukázka 5: Ž 1,1-3²

\section{TPD}

${ }^{1}$ Hej, scęśliwy ctek, co ze złymi nie staje w gromadzie, ani stopy swojej na pyrci grzysnej nie ktadzie, ani siado na pniocku, ka tacy siadujom co sie z kozdej porady mądrej wyśmiewajom.

${ }^{2}$ Jacy wdy mo na myśli za tym zabieganie, coby $w$ prawie Pańskim mieć upodobanie. Kondycyje święte trzymie $w$ dzień $i$ w nocy, bez ustanku wozy, ka stanie, ka krocy.

${ }^{3}$ Taki podobny bedzie drzewku ogrodnemu, które kozdego roku rodzi owoc gazdowi swojemu.

Liście jego nie zótknom, bo na casie kwitnie, temu syćko co pocnie, wyjdzie akuratnie.

\section{Kochanowski (1579)}

${ }^{1}$ Szczęśliwy, który nie byt miedzy złymi $w$ radzie

Ani stóp swoich torem grzesznych ludzi ktadzie

Ani siadt na stolicy, gdzie tacy siadaja,

Co się z nauki zdrowej radzi naśmiewaja;

2 Ale to jego umyst, to jego staranie,

Aby na wszytkim petnit Pańskie przykazanie;

Dzień li po niebie wiedzie, noc li swoje konie,

${ }_{41}$ Viz autorův doslov $\mathrm{k} T P D$.

42 Pro lepší orientaci jsem přidal v TPD i u Kochanowského číslování versetů. 
On ustawicznie w Pańskim rozmyśla zakonie.

${ }^{3}$ Taki podobien będzie drzewu porzecznemu, Które przynosi co rok owoc panu swemu, Liścia nigdy nie tracac, choć zła chwila przydzie;

Temu wszystko, co pocznie, na dobre wynidzie.

ČEP ${ }^{1}$ Blaze muži, který se neř́di radami svévolnikü, který nestojí na cestě hř́šných, který nesedává s posmèvači, ${ }^{2}$ nýbrž si oblibil Hospodinův zákon, nad jeho zákonem rozjímá ve dne i v noci. ${ }^{3} \mathrm{Je}$ jako strom zasazený u tekoucí vody, který dává své ovoce v pravý čas, jemuž listí neuvadá. Vše, co podnikne, se zdaŕí.

V ukázce vidíme jednak typické znaky dialektu, zejména $\mathrm{v}$ hláskosloví (např. malopolské mazuření: v. 1 ctek „člověk“, pol. człowiek; grzyșnej „hříšné“, pol. grzesznej; v. 3 kozdego „každého“, pol. każdego; podobně jako v NTG ani zde není uplatněn podhalanský archaismus: syćko „Všechno“, pol. wszystko - „důsledně podhalansky“ by bylo sýćcko) a lexiku (např. v. 1 hej, částice otvírající výpověd, častá ve folklorních písních; pyrć „úzká vysokohorská stezka“; pniocek „pařez, špalek“, pol. pniaczek, pieniek, zde jako ekvivalent pro „stolec, sedadlo“; v. 3 gazda „hospodář“, pol. gospodarz). Především pak Bachledovy veršované žalmy představují zajímavý pokus uvést do nářečí rysy knižního stylu, či dokonce modelovat pro dialekt „povznesený“ styl biblický, a to dokonce inspirací u nejvýznamnějšího polského básníka staré doby. Tuto tendenci pak vidíme v pozoruhodné kombinaci s experimentem užití „vypjatých“ lexikálních dialektismů, které navíc někdy ukazují ke specifickým reáliím života obyvatel hor (pyrć, pniocek). V řadě řešení pak je na první pohled zřejmé, že jde o celkem nápadité variace na verše Kochanowského.

\subsection{Janovo evangelium v mluvě hiphopové mládeže}

Poslední z biblických adaptací, které se budeme věnovat, je text nikoli už v místním (lokálním) dialektu, nýbrž v „dialektu“ sociálním, sociolektu, čili ve specifické mluvě konkrétní sociální skupiny (jako je např. jazyk-slang myslivců, studentů, zločinců). V našem případě se jedná o mluvu mládeže, konkrétně ze subkultury definované hudbou a životním stylem hip-hopu. 
V polském prostředí je fenomén mluvy mládeže, zvláště studentů, dost živý, ${ }^{43}$ významně rozvinutější a proměnlivější než v češtině. Specifické jazykové prostředí pak představuje velkoměstská subkultura spojená s hip-hopem - ta je také výraznější a o poznání rozšířenější než v Česku. Varšavská pedagožka Beata Lasota, věnující se v první polovině první dekády nového milénia mládeži v mimoškolní době, a její dvě mladší kolegyně Asia Rafał a Basia Sieradz (středoškolačky, posléze studentky - první z nich pedagogické fakulty, druhá aplikované lingvistiky a žurnalistiky) se rozhodly adaptovat do mluvy polské hiphopové mládeže text celého Janova evangelia. Nejprve publikovaly některé pasáže na internetu, v létě 2006 vydaly celý text knižně. Svazek nazvaly Dobra czytanka wedtug świętego ziom'a Janka („Dobrá čítanka podle svatého kámoše Janka“; zavádím značku $D C z) .{ }^{44}$ Příznačné je, že už sám název obsahuje výrazný slangismus ziom: je dotvořen z oživeného starého polského slova ziomek (původně znamenajícího „člověk ze stejné země“, „krajan“, „našinec“) a spolu s ním se mezi mládeží běžně užívá jako ekvivalent amerického slangového homie, homeboy „kámoš, člen našeho gangu“.

Ukázka 6: J 1,24-30.32.34

DCz ${ }^{24}$ A ci kolesie byli od faryzeuszów. ${ }^{25}$ I zagadneli go: No to czemu zanurzasz w wodzie, jeśli nie jesteś Mesjaszem ani Eliaszem, ani prorokiem, hmm... ${ }^{26}$ Jan do nich: Ja zanurzam w wodzie, ale u was jest ten, którego nie znacie. ${ }^{27}$ Ten, co wbije sie po mnie i któremu normalnie nie jestem godny nawet sznurówek $w$ adidasach zawiazać. ${ }^{28}$ A cata ta akcja byta w Betabarze za Jordanem, gdzie wtaśnie Jan zanurzat w wodzie, czyli chrzcit. ${ }^{29}$ Następnego dnia Jan przylukat Jezusa, jak szedt do niego i powiedziat: To jest Baranek Boży. On kasuje wine świata. ${ }^{30}$ To jest ten, co o nim już nawijałem, że wbije się po mnie, chociaż byt wcześniej niż ja. [...]». ${ }^{32}$ Jan gadat tė̇ o tym, że widział Ducha schodzacego z nieba, coś jak gotębica, który usiadt na Jezusie. [...] ${ }^{54}$ A ja tẹ akcje widziatem i potwierdzam, że on jest Synem Boga.

43 Souhrnně viz např. Ewa Baniecka, „Gwara młodzieżowa jako odmiana współczesnej polszczyzny - próba charakterystyki“, Studia Gdańskie. Wizje i rzeczywistość, t. 5 (2008):157-169 a Beata Jarosz, „O zasięgu słownictwa socjolektalnego w XXI wieku”, Białostockie Archiwum Językowe, 13 (2013): 97-116, doi: 10.15290/baj.2013.13.07. K dispozici je už několik obsáhlých slovníků, např. Bartek Chaciński, Totalny słownik najmłodszej polszczyzny (Kraków: Znak, 2007).

44 Dobra czytanka wg świętego ziom'a Janka, Przekład i stylizacja językowa: Asia Rafał, Basia Sieradz, Beata Lasota (Warszawa: Selah Time, 2006). 
BT ${ }^{24}$ A wystannicy byli spośród faryzeuszów. ${ }^{25}$ I zadawali mu pytania, mówiac do niego: "Czemu zatem chrzcisz, skoro nie jesteś ani Mesjaszem, ani Eliaszem, ani prorokiem?» ${ }^{26}$ Jan im tak odpowiedziat: "Ja chrzcze woda. Pośród was stoi Ten, którego wy nie znacie, ${ }^{27}$ który po mnie idzie, a któremu ja nie jestem godzien odwiazać rzemyka u Jego sandała». ${ }^{28}$ Dziato sie to $w$ Betanii, po drugiej stronie Jordanu, gdzie Jan udzielat chrztu. ${ }^{29}$ Nazajutrz zobaczyt Jezusa, nadchodzacego ku niemu, i rzekt: «Oto Baranek Boży, który gtadzi grzech świata. ${ }^{30}$ To jest Ten, o którym powiedziałem: Po mnie przyjdzie Mą̇, który mnie przewyższyt godnościa, gdyż byt wcześniej ode mnie. [...]». ${ }^{32}$ Jan dał takie świadectwo: «Ujrzałem Ducha, który jak gotębica zstępowat $z$ nieba i spoczat na Nim. [...] ${ }^{34}$ Ja to ujrzałem i daje świadectwo, że On jest Synem Bożym».

ČEP ${ }^{24}$ Ti vyslaní byli $z$ rad farizeů. ${ }^{25}$ Otázali se ho: „Proč tedy křtíš, když nejsi ani Mesiáš ani Eliáš ani ten Prorok?" ${ }^{26}$ Jan jim odpovédél: „Já kŕtím vodou. Uprostred vás stojí, koho vy neznáte - ${ }^{27}$ ten, který pricházi za mnou; jemu nejsem hoden ani rozvázat remínek u jeho obuvi”. ${ }^{28}$ To se stalo v Betanii, na druhém brehu Jordánu, kde Jan kŕtil. ${ }^{29}$ Druhého dne spatřil Jan Ježíše, jak jde k nému, a rekl: „Hle, beránek Boži, který snimá hrích svéta. ${ }^{30}$ To je ten, o némž jsem rekl: Za mnou pricházi nékdo vétší, nebot' byl dřive nežz já. [...] “. ${ }^{32}$ Jan vydal svědectví: „Spatril jsem, jak Duch sestoupil jako holubice z nebe a zůstal na ném. [...] ${ }^{34}$ Já jsem to vidél a dosvédčuji, že toto je Syn Božì”.

Jako typický sociolekt je i mluva hiphopová založena zejména na specifické slovní zásobě a frazeologii, která činí tento kód pro nezasvěcence místy až temným, nesrozumitelným. Dobra Czytanka je tedy prosycena jazykovými „neobvyklostmi“, příznakovými elementy různého typu: v ukázce je jasně vidět, jak vysoké procento tvoří podtržené části textu, tj. výrazně „neobvyklé“ lexémy a obraty. Časté jsou zde běžné hovorové prvky i méně či více specifické prvky mládežnického a hiphopového sociolektu, častý je příznak expresivity. Př́íklady těchto kolokvialismů a slangismů: v. 24 koleś „chlapík, typan, týpek“ (spíš pozitivně zabarvené, avšak někdy i pohrdlivé); v. 25 zagadnać „začít s někým rozhovor, promluvit“; v. 30 nawijać „povídat, kecat“ (původně „motat, namotávat"); wbić się „dostat se, přijít“ (pův. „,vecpat se“). Vedle toho lze občas narazit na vysvětlující ekvivalent (v. 28 zanurzać $w$ wodzie „ponořovat do vody“), výjimečně i na modernizující, aktualizující prvek, který jakoby „přenáší“ děj do dnešní doby, ba výslovně do prostředí hip-hopu (v. 27 któremu normalnie nie jestem godny 
nawet sznurówek $w$ adidasach zawiazać „kterému fakt nejsem hoden ani zavázat tkaničky u tenisek“). Zároveň je nutno podtrhnout, že jde o mládežnickou a hiphopovou mluvu zvláštním způsobem stylizovanou - v textu je totiž zároveň zachováno leccos z „tradičního“ biblického jazyka, zvláště výrazy terminologického charakteru: Syn Boży, Baranek Boży, prorok, chrzcić „křtít", grzech „hřích“.

\section{Další aspekty a závěr}

Zbývá doplnit aspoň stručný pohled na některé další důležité skutečnosti, doprovázející vznik a „Život“ představených nestandardních biblických textů.

\subsection{Motivace tvůrců}

Nepominutelnou otázkou je, jaké jsou hlavní motivace tvůrců polských biblických textů v nestandardních jazykových podobách? Z úvodů k jednotlivým počinům, ze zpráv a rozhovorů v médiích i z odborných statí vyplývá, že prakticky všechny texty (zvláště ty „větší“) byly míněny ve vyšší či nižší míře jako určitý příspěvek k šíření evangelia, povzbuzení zbožnosti skupin spojených užíváním daného jazykového kódu. Nejzřetelnější to asi je u hiphopové adaptace, která vznikla přímo s jednoznačným cílem pokusit se přiblížit Ježíšovo poselství zvláštní společenské skupině, pro kterou je Písmo svaté v obvyklé podobě často textem (téměř) neznámým nebo dost nesnadno čitelným. Hiphopové prostředí v Polsku je poměrně silné a nechybějí v něm velké problémy jako závislost na drogách, patří k němu lidé hledající zoufale svou identitu a pevnější zakotvení v životě atd. Pro usnadnění jejich cesty k Písmu svatému byla tedy vytvořena Dobra Czytanka.

O slezských adaptacích lze v zásadě všeobecně konstatovat, že za jejich vznikem a popularitou stojí také větší či menší akcent lokálně patriotický, a to často i v politickém smyslu. Souvisí to se společenským kvašením v polském Slezsku od devadesátých let 20. století: objevuje se autonomistické hnutí, leckdy spojené s distancí vůči „polskosti“ nebo i s nostalgií po „prušáckém“ období a s hledáním německých rodinných kořenů (mnohdy z ekonomických důvodů). Pokusy o „zliterárnění" slezštiny (vlastně různých slezštin, navzájem dost odlišných, srov. výše) jdou často ruku v ruce s vymezováním vủči standardní polštině (i v krajní poloze: slezština není součástí polštiny), delší dobu jsou viditelné také snahy o prosazení slezštiny jako 
regionálního jazyka. ${ }^{45} \mathrm{~A}$ právě také biblický text, jak se zdá, by mohl výrazně napomoci k „vytaženi“ mladého kulturního dialektu na úroveň vyšší prestiže. ${ }^{46}$

V podhalanském góralském prostredí se zdá, že jde o trochu odlišný druh prožívání a vyjádření vztahu k rodnému kraji než ve slezském případě. Na rozdíl od Slezska zde úplně chybějí nějaké ambice politické (autonomistické): asi prakticky nikdo z Góralů nebude tvrdit, že jeho mluva snad není součástí polštiny. Spíš tu vidíme pokusy posílit archaickou svébytnou lokální kulturu, která je stále ještě živá, ale před očima odchází (týká se to hudby, krojů, užívání mluveného dialektu atd.). Je zde tedy patrně snaha v textu góralského Písma svatého zafixovat, zakonzervovat, „vytesat do kamene“ dialekt, který z živého užívání mizí. A zároveň obecně povzbudit sympatie ke kraji i u těch, kdo se odstěhovali nebo kdo sem jezdí jen na dovolenou či za přáteli. Góralský přístup je, zdá se, defenzivnější, nostalgičtější (snad lze dokonce říci: naivnější), než jsou „dravější" a cílenější motivy a tendence slezské. ${ }^{47}$

\subsection{Reakce a ohlasy na nestandardní podoby biblického textu}

Je třeba podtrhnout, že hlavně první počiny (texty objevivší se mezi lety 2000 a 2006) vyvolaly poměrně velkou diskusi v médiích a také v odborných kruzích, ovšem více asi filologických než teologických. Na téma postupně se objevujících adaptací biblického textu se objevila řada reakcí, nejvíce asi v letech 2003 až 2007 (tedy když už byly $\mathrm{k}$ dispozici tiskem publikované nebo alespoň na internetu zveřejněné rozsáhlejší biblické texty ve slezštině, góralštině i v hiphopovém sociolektu). Nejvýraznější a nejvážnější dobovou reakcí, která rezonuje až do současnosti, bylo prohlášení Rady języka polskiego przy Prezydium Polskiej Akademii Nauk, resp. jejího Výboru pro náboženský jazyk

45 Srov. výše pozn. 8. V červnu 2019 se polský Sejm rozhodl nezabývat návrhem zákona, podle nějž by slezština byla uznána za regionální jazyk (je to již pátý neúspěšný slezský pokus o dosažení statutu regionálního jazyka od r. 2007).

46 Např. M. Szołtysek (který není žádným radikálním autonomistou) výslovně zmiňuje, že $B S ́$ vytvořil mj. proto, aby vytříbil slezštinu pro vážnější literaturu, hlubší témata (srov. $B S$, s. 4).

47 Rozdílné procesy konstituování „kulturního dialektu“ slezského a góralského vystihuje např. Artur Czesak, „Góralski i śląski - mikrojęzyki literackie in statu nascendi?", Slavic literary microlanguages and language contacts, ed. Alexandr Dulichenko - Sven Gustavsson (Tartu: Tartu University Press, 2006), 360-385. 
(Komisja języka religijnego), z podzimu $2005 .{ }^{48}$ Formulace prohlášení byly výrazně kritické vůči textu slezskému (BŚ), góralskému (NTG) i hiphopovému $(D C z)$. Podepsaní členové výboru jsou přední polonisté (dialektologové i stylistici) a nechybějí ani teologové. Na podzim 2006 se konala v Gródku nad Dunajcem velká interdisciplinární konference o biblickém jazyce, kde byla významně ventilována i problematika adaptací do dialektů a sociolektu. ${ }^{49}$ Odborné dílčí studie reagující z různých pohledů (translatologie, stylistiky, sociolingvistiky, dialektologie) na dotyčné biblické texty se pak objevují i mnoho let po jejich vydání. ${ }^{50}$

Naopak v samých prostředích, jimž byly adaptace primárně určeny, bylo přijetí textů patrně dosti prríznivé. I Dobra Czytanka, které byla leckdy v internetových diskusích vyčítána jazyková nevhodnost až profanace nebo někdy naopak (ze strany některých přívrženců hip-hopu) určitá „umělost“ zvoleného jazyka (kdy se např. vedle mnoha slangismů řada tradičních biblických elementů typu faryzeusze ponechává bez vysvětlení), byla úspěšně představena $\mathrm{v}$ různých polských městech formou autorských čtení i v médiích, uplatnila se na křestanských hiphopových festivalech, občas ji používají také někteří katecheti.

Už jsem se zmínil o obrovském prodejním úspěchu Biblii Ślazoka (viz výše v subkap. 2.1.1), který svědčí o pozitivním přijetí u mnoha

48 Jde o dokument Uwagi o wspótczesnych przektadach Biblii; 5. 9. 2019 dostupné na adrese https://bit.ly/2C9sZPd.

49 Podrobný referát o této konferenci je k dispozici na internetové straně Rady Języka Polskiego: https://bit.ly/2WsEOXx. Příspěvky z konference vyšly tiskem ve dvojsvazkové publikaci Polszczyzna biblijna między tradycja a wspótczesnościa, I, II, red. Stanisław Koziara - Wiesław Przyczyna (Tarnów: Biblos, 2009).

50 Texty slezské a góralské od počátku sleduje zejména dialektolog A. Czesak, např.: Artur Czesak, „Czy możliwa jest Biblia po śląsku? Stereotypy Ślązaków i ich mowy,“ Między oryginatem i przektadem VIII (2003): 69-78; Artur Czesak, „Ewangelie po góralsku czytane przez dialektologa“, aneks [9 s.] do tomu Góry i góralszczyzna $w$ dziejach i kulturze pogranicza polsko-stowackiego (Podhale, Spisz, Orawa, Gorce, Pieniny). Literatura i język, red. M. Madejowa - A. Mlekodaj - K. Sikora (Nowy Targ: PPWSZ, 2005). Řadu slezských biblických pokusů (i menších nebo internetových) i počiny góralské komentuje také v rámci své nedávné monografie zasvěcené hlavně moderním snahám o vytvoření standardní slezštiny a rozvoji slezské literatury: Artur Czesak, Wspótczesne teksty ślaskie na tle procesów językotwórczych i standaryzacyjnych wspótczesnej słowiańszczyzny (Kraków: Księgarnia akademicka, 2015), 145-164. K nejvýznamnějším analýzám hiphopového textu patří stati: Paweł Plichta, „,Zobaczysz jeszcze bardziej hardkorowe jazdy niż ta‘ (J 1,50) : święty lans“ współczesnej narracji kulturowej“, Przeszłość we współczesnej narracji kulturowej. Studia i szkice kulturoznawcze, t. 2, red. Paweł Plichta (Kraków: Wyd. UJ, 2011), 127-157; Tomasz Lisowski - Przemysław Wiatrowski, „Dobra Czytanka wg św. ziom'a Janka a tradycja polskiego stylu biblijnego“, Poznańskie Studia Polonistyczne. Seria językoznawcza 20/40, z. 2 (2013): 115-127, doi: 10.14746/pspsj.2013.20.2.11. 
Slezanů a fanoušků slezanství (at' už vymezeného jakkoli). Mimořádný zájem vzbudil později i Nowy Testamynt po ślonsku, který byl rozprodán během roku a půl od vydání (přes omezené možnosti nákupu - v podstatě bylo možno knihu pořídit jen v několika vybraných knihkupectvích a u samého autora). ${ }^{51}$

Góralské texty (novozákonní a snad i žalmy z TPD) se dokonce brzy po vydání začaly používat na několika místech regionu i při liturgii (v rámci tzv. mší $w$ oprawie góralskiej, při nichž hudbu obstarávají lidové kapely a na něž mnoho věřících přichází v tradičních krojích). Tato skutečnost záhy (v listopadu 2005) vyvolala jako kritickou reakci „list pro memoria“ arcibiskupa krakovského Stanisława kardinála Dziwisze, v němž hierarcha vybízí duchovní k dodržování liturgických předpisů, což znamená také užívání jen oficiálně schválených biblických textů. ${ }^{52}$ To byl asi nejviditelnější kritický hlas z kruhů církevních autorit a mezi věřícími Góraly a sympatizanty vyvolal určité zmatení (kritizované knihy totiž vydalo církevní-řeholní nakladatelství Pallotinum, předmluvy s úchvalným zabarvením napsali kněží) a rozčarování. Důsledkem arcibiskupova ohrazení (i výtek z jiných stran) byla pravděpodobně i skutečnost, že M. Matejowa-Torbiarz už ve svém projektu vydávání biblických textů v dialektu dál nepokračovala..$^{53}$ Zajímavou skutečností je, že text $N T G$ byl patrně občas liturgicky užíván také mezi Góraly žijícími na slovenské straně. ${ }^{54}$

51 Strana Biblia po ślasku na sociální síti Facebook oznámila 28. dubna 2019, že je k dispozici už jen sedmdesát výtisků, 15. července 2019 pak sdělila, že náklad již byl vyčerpán.

52 Jde o dokument Pro memoria o tzw. mszach św. „w góralskiej oprawie“; 5. 9. 2019 dostupné na adrese https://bit.ly/32rCFz8.

53 Na začátku r. 2005 se sama M. Matejowa Torbiarz zmiňuje o existenci mešního lekcionáře a o tom, že má již přeložený i text knihy Genesis, viz Marta Dvořák, „W księgarniach już jest Nowy Testament przetłumaczony na gwarę zakopiańskich górali“ (4. 4. 2019 dostupné na adrese https://bit.ly/2WInxdd). K vydání knihy Genesis tiskem patrně už nedošlo, mešní lekcionář snad vyšel jen jako malotirážní tisk (nenalezl jsem o něm žádnou informaci v bibliografiích a knihovních katalozích; nevědí o něm ani krakovští polonisté zabývající se nářečími a literárními aktivitami v dané oblasti; samu autorku se mi žel nepodařilo kontaktovat).

54 Např. v rámci Góralských folklórních slavností v obci Ždiar r. 2008 se při mši četlo evangelium z NTG (dokonce s malými úpravami - aby text lépe odpovídal zdejšímu nářečí), po přečtení perikopy ve slovenštině (informace z korespondence $\mathrm{s}$ jáhnem př́tomným bohoslužbě). 


\subsection{Výhled do budoucna}

Hlavním východiskem kritických ohlasů je neoddiskutovatelná skutečnost jistého vícestranného amatérismu, který lze najít v pozadí prakticky všech zmíněných počinů. Téměř vždy jde o kvazipřeklady, překlady z překladu. I v př́padě, že se překládá z originálu, není autor přímo klasický filolog či biblista. Tvůrci jsou vesměs nadšenci, kteří se (někdy) typicky zaštitují „konzultacemi s odborníky“. Totéž platí i směrem k církevní autoritě. Žádný z textů nemá přrislušné církevní schválení, a tudíž podporu významné formální autority. Autoři nebo vydavatelé si pomáhají tak, že knihu vypraví „na biblický způsob“ (zlatý nadpis na důstojných tmavých deskách apod.), do publikace zařadí přejný doprovodný text (úvod, dopis či jiný ohlas) některého z duchovních, dedikaci papeži atd. To vše je ale právě stále v linii onoho zmíněného amatérismu. Budou-li tedy chtít slezští či góralští literáti, aby biblický text v jejich dialektu nebyl viděn spíš jen jako lokální kuriozita, ale aby byl obecněji přijat i v odborných, církevních a širších kulturních kruzích s respektem (tj. aby mu byla bez velkých rozpaků přiznávána potřebná míra „kvality“), stěží se mohou v budoucích revizích nebo nových pokusech vyhnout mravenčí práci, kterou lze už dlouho pozorovat u zmíněných Kašubů. ${ }^{55}$ Ti k vytváření svých biblických textů přistupovali a přistupují již desítky let mnohem promyšleněji a profesionálněji, nejenom s entuziasmem, ale také v úzké součinnosti s filologií, biblistikou i církevními autoritami. A teprve od takového solidně vypracovaného, obecně respektovaného biblického textu lze zároveň očekávat, že může být pomocí také při snaze „vytáhnout“ daný dialekt na úroveň vyšší společenské prestiže.

Pokud jde o experiment biblického textu ve stylizovaném sociolektu, zdá se, že asi nelze ani dnes, kdy uplynula poměrně dlouhá doba od jeho vzniku, ještě jednoznačně rríci, zda vůbec a v jaké míře jsou jazykové prvky daného typu pro biblický text (jakkoli specificky zaměřený) „seriózně“ uplatnitelné. Zejména jde o to, aby jejich přílišná nápadnost a kontroverznost, tedy specifická, místy dosti krajní jazyková příznakovost, nezahlušila něco důležitého z jádra biblického poselství. Kontroverzní text Dobrej Czytanki wg świętego ziom'a Janka, ač na první pohled vypadá jako pouhá jazyková hříčka, podle mého názoru stále ještě čeká na podrobnou, vícestrannou, komplexní studii, která by zároveň zohlednila aspekty translatologické, stylistické,

55 Srov. výše v úvodu ke kap. 2. 
sociolingvistické, biblistické i pastorální a která by jistě mohla přinést i řadu impulzů obecnějších.

Jak bylo řečeno úvodem, převedení biblického textu do lokálního dialektu či do jazykového útvaru typu sociolektu je jev, pro nějž v našem českém jazykovém prostředí nenacházíme paralelu. $V$ dalších západoslovanských jazycích nicméně analogické počiny existují: na Slovensku byla nedávno publikována čtyři evangelia ve spišském dialektu, ${ }^{56}$ nejnověji pak se objevily dokonce i texty z malé oblasti lužickosrbské (biblické úryvky ve východostředolužickém dialektu regionu městečka Slepo). ${ }^{57}$ Podobné pokusy se množí také ve vzdálenějších evropských regionech, např. ve Francii, Německu či Itáliii, ${ }^{58}$ a v budoucnu by patrně stálo za to nahlédnout daný fenomén i v těchto širších souvislostech.

Katolická teologická fakulta, Univerzita Karlova

Thákurova 3

16000 Praha 6

E-mail: josef.barton@ktf.cuni.cz

${ }^{56}$ Anton Kret - Ladislav Vrana, Evanjelium Ježiša Krista v spišskom náreči (Bratislava: Karmelitánske nakladatel'stvo, 2011).

57 Čtyři celé žalmy, Otčenáš a některé jiné krátké biblické úryvky v tomto mikrojazyce byly publikovány v novém evangelickém zpěvníku Něnter comy Boga chwalić. Slèpjańske spiwarske knigty (Slěpe: Kólesko, 2019).

58 Příklady: nedávný překlad obou Zákonů do klasické (sjednocené) okcitánštiny: $L a$ Bíblia: Ancian Testament, traduccion de Joan Larzac (Toulouse: Letras d'òc, 2013); La Bíblia: Novèl Testament, traduccion de Joan Larzac (Toulouse: Letras d'òc, 2016); tlumočení evangelia Matoušova do gaskoňštiny (z devadesátých let): Evangèli segon sant Mateu, traduccion occitana (gascona) confrontada à l'originau grèc, per Miquèu Grosclaude (Pau: Per Noste, 1995); zbrusu nový překlad celého Nového zákona do západofalcké němčiny (v pdf; text byl dostupný ke dni 20.12. 2019 na adrese https:// bit.ly/2ZA1NBR; autorem překladu je Dieter Zimmer, jméno v knize není uvedeno); projekt prvního překladu celého Písma do standardní (dolomitské) ladinštiny probíhající na Svobodné univerzitě v Bolzanu (od r. 2012), srov. Ruth Videsott, „La traduzione della Sacra Scrittura nel ladino dolomitico: rilevanza e difficoltà “, Biblicum Jassyense 5 (2014): 71-86. 